\title{
Effect of repeated electrical breakdowns on mineral and natural ester insulating oils
}

\author{
Sharin Ab Ghani ${ }^{1}$, Mohd Shahril Ahmad Khiar ${ }^{2}$, Imran Sutan Chairul ${ }^{3}$, Muhammad Imran Zamir ${ }^{4}$ \\ ${ }^{1,2,3}$ High Voltage Engineering Research Laboratory, Faculty of Electrical Engineering, Universiti Teknikal Malaysia \\ Melaka, Malaysia \\ ${ }^{4}$ SBS Letrik Sdn. Bhd., Kedah, Malaysia
}

\begin{tabular}{l} 
Article Info \\
\hline Article history: \\
Received Jul 29, 2021 \\
Revised Sep 4, 2021 \\
Accepted Oct 31, 2021 \\
\hline
\end{tabular}

\section{Keywords:}

Breakdown voltage

Durability

Mineral oil

Natural ester oil

Transformer oil

\begin{abstract}
Transformer insulating oils are exposed to repeated electrical discharge or breakdowns inside power transformers. Durability tests are conducted to analyze the ability of oil to resist decomposition due to such high electrical stresses. With the increasing demand for alternative insulating oils for oilimmersed transformers, it is worthy to compare the performance of different types of insulating oils (conventional mineral-based insulating oil and natural ester-based insulating oil) under repeated electrical breakdown. In this paper, the AC breakdown voltage of different mineral-based and natural ester-based insulating oils is reported. Durability tests were conducted based on the AC breakdown voltage behavior of insulating oils after 50 electrical breakdown shots. The AC breakdown voltage of each insulating oil sample was assessed according to the ASTM D1816 standard test method. Based on the results, it can be concluded that the dissimilarity in chemical composition of the insulating oils has a significant effect on the AC breakdown voltage behavior of these oils under repeated electrical breakdowns.
\end{abstract}

This is an open access article under the CC BY-SA license.

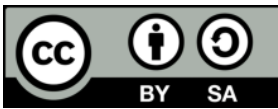

\section{Corresponding Author:}

Sharin Ab Ghani

High Voltage Engineering Research Laboratory

Faculty of Electrical Engineering

Universiti Teknikal Malaysia Melaka

Hang Tuah Jaya, 76100 Durian Tunggal, Melaka, Malaysia

Email: sharinag@utem.edu.my

\section{INTRODUCTION}

Mineral-based insulating oils are widely used as an insulating medium in oil-immersed transformers, enabling safe and reliable electrical energy transmission. Mineral-based insulating oils derived from petroleum were the first insulating oils used in oil-immersed power transformers. Mineral-based insulating oils have been widely used since the 1940s in power equipment such as transformers, capacitors, cables, and bushings [1]-[3]. However, mineral-based insulating oils do not provide the necessary protection against fire hazards. Qualifying transformer insulating oils must meet a minimum open-cup fire point of $300^{\circ} \mathrm{C}$. A systematic research and development program began in the early 1990 s due to environmental regulations and liability concerns by introducing natural ester-based insulating oils. Recently, studies have been carried out to develop natural ester-based insulating oils due to environmental concerns associated with mineral-based insulating oils [2], [3]. The quest to develop environmentally friendly insulating oils stems from the following reasons [4]. First, in the event of a severe spill, mineral-based insulating oils can contaminate soil and water resources. Second, mineral-based insulating oils are derived from petroleum, which will deplete in the future because petroleum is a non-renewable energy source. Researchers concluded 
that natural ester-based insulating oils can be chemically enhanced to improve their physicochemical and electrical properties such as oxidation stability, dissipation factor, lightning impulse resistance, and viscosity [5], [6]. Table 1 shows the specifications for mineral-based and natural ester-based insulating oils according to the ASTM D3487 and ASTM D6871 standards [7], [8].

Table 1. Specifications for the physicochemical and electrical properties of mineral-based and natural esterbased insulating oils

\begin{tabular}{ccccc}
\hline & Properties & ASTM standard test method & $\begin{array}{c}\text { Mineral oil } \\
\text { (ASTM D3487) }\end{array}$ & $\begin{array}{c}\text { Natural ester } \\
\text { (ASTM D6871) }\end{array}$ \\
\hline \multirow{2}{*}{ Electrical properties } & AC breakdown voltage (kV) & D1816 (1-mm gap) & $\geq 20$ & $\geq 20$ \\
Chemical properties & D1816 (2-mm gap) & $\geq 35$ & $\leq 35$ \\
& Water content (ppm) & D1533 & $\leq 200$ & $\leq 0.6$ \\
Physical properties & Acid value (mg KOH/g) & D974 & $\leq 0.5$ & $\leq 1.0$ \\
& Visual examination & D1500 & D1524 & Clear and bright Clear and bright \\
\hline
\end{tabular}

Electrical breakdown occurs when the insulating oil becomes a conductor under the influence of a high voltage stress [9], [10]. In power transformers, the insulating oil is continuously exposed to repeated electrical discharge, resulting in breakdown of electrical insulation. Since the electrical discharge is unavoidable, it is important to understand the behavior of insulating oil properties under repeated electrical discharge to avoid insulation failure and breakdown of the transformer. The ability of the insulating oil to resist decomposition under repeated electrical discharge is one of the important factors for the safety of the transformer. Repeated electrical discharge in the presence of heat, moisture, and oxygen will oxidize the insulating oil and produce free radicals, acids, and sludge that are harmful to the transformer [11], [12]. Hence, it is crucial to study the durability of the mineral-based and natural ester-based insulating oils in terms of the AC breakdown voltage in order to prevent catastrophic failure of power transformers.

\section{RESEARCH METHOD}

In this study, Hyrax Hypertrans ${ }^{\mathrm{TM}}$ uninhibited mineral insulating oil was chosen as the mineralbased insulating oil, hereinafter MI oil. Envirotemp FR3 ${ }^{\text {TM }}$ (formulated with soybean oil) was chosen as the natural ester-based insulating oil, hereinafter NEI oil. Pre-processing was first carried out to remove foreign particles and moisture from the NEI oil. The insulating oil samples were filtered through quantitative filter paper with a pore size of $2 \mu \mathrm{m}$. The insulating oil samples were then heated in a vacuum oven for $48 \mathrm{~h}$ at a temperature of $70{ }^{\circ} \mathrm{C}$ and vacuum pressure of less than $1 \mathrm{kPa}$ [13], [14]. A portable oil AC breakdown voltage tester (Model: OTS60PB, Megger Ltd., UK) equipped with semi-spherical electrodes was used to conduct the AC breakdown voltage tests. This instrument can be used to test an insulating oil sample with a volume of $500 \mathrm{ml}$. The oils were left at an ambient temperature of $\sim 20-30^{\circ} \mathrm{C}$. The ambient relative humidity and oil temperature were measured using a calibrated hygrometer and thermometer, respectively. Next, the containers of the oil samples were gently inverted and swirled several times to ensure homogeneity of the oils. Within 1 min after agitation, the test cell was rinsed with a small amount of the insulating oil sample. Following this, the test cell was drained.

Next, the remaining portion of the oil sample was slowly poured into the test cell and the test cell was closed to prevent air from contacting the insulating oil. The insulating oil sample was left for 3-5 min before application of the first breakdown voltage. However, for insulating oils with a high fire point such as natural ester and synthetic ester, the hold time before the initial application of breakdown voltage is at least $30 \mathrm{~min}$. The breakdown voltage was automatically applied at an increment of $0.5 \mathrm{kV} / \mathrm{s}$ until breakdown occurred. Nine additional tests were conducted, where the time between breakdowns was 1.0-1.5 min. In this study, three samples from each insulating oil (MI and NEI) were taken from the same sources for the AC breakdown voltage test. Each oil sample was tested for 10 consecutive electrical breakdowns five times, resulting in 50 data points. The data for the MI and NEI oils were analyzed statistically in order to determine the mean and standard deviation of the AC breakdown voltage. The details of the AC breakdown voltage test according to the ASTM D1816 standard test method are summarized in Table 2 and Figure 1 shows the steps involved before the AC breakdown voltage test. 
Table 2. Details of the AC breakdown voltage test according to the ASTM D1816 standard test method

\begin{tabular}{|c|c|c|}
\hline \multicolumn{3}{|c|}{ ASTM D1816 standard test method } \\
\hline Electrode & Shape & Spherical \\
\hline & Gap distance & $1 \mathrm{~mm}$ or $2 \mathrm{~mm}$ \\
\hline Laboratory test temperature & Liquid & Must be recorded at ambient temperature \\
\hline & Ambient & $20-30^{\circ} \mathrm{C}$ \\
\hline Test voltage & Rate of applied voltage increment & $0.5 \mathrm{kV} / \mathrm{s}$ \\
\hline & Frequency & $45-65 \mathrm{~Hz}$ \\
\hline Breakdown & Number of breakdowns in sequence & 5 \\
\hline & Time between breakdowns & $1.0-1.5 \mathrm{~min}$ \\
\hline
\end{tabular}
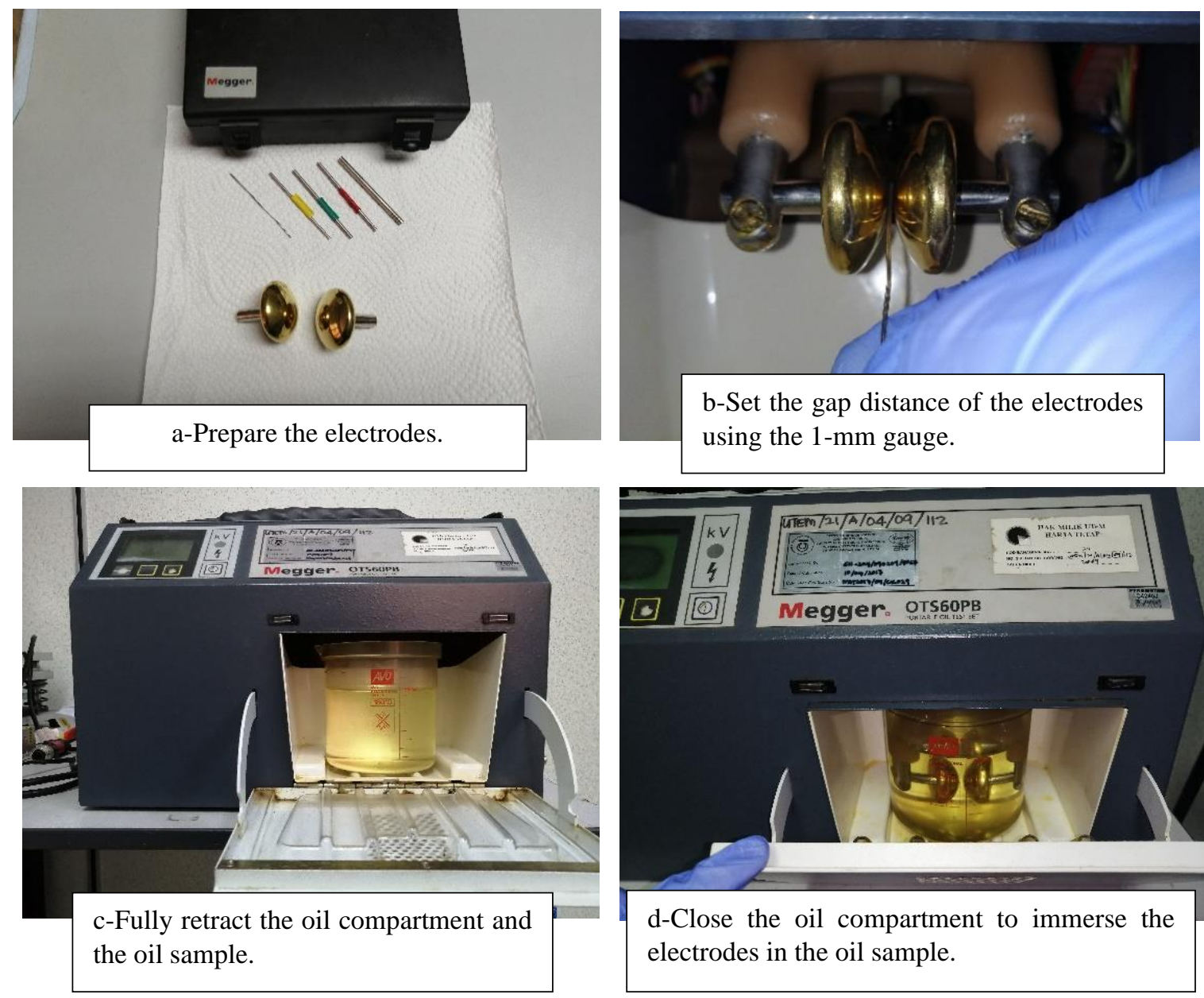

Figure 1. Steps involved before the AC breakdown voltage test

\section{RESULTS AND DISCUSSION}

The AC breakdown voltage is the voltage where discharge occurs between the electrodes immersed in the insulating oil. Table 3 shows the results of AC breakdown voltage test for the MI and NEI oils, where three samples were prepared for each oil, and each sample was subjected to 10 consecutive electrical breakdown shots five times. The average AC breakdown voltage and standard deviation were determined for each sample. Based on the results, the average AC breakdown voltage of the three MI oil samples is within a range of $21-24 \mathrm{kV}$. The minimum $\mathrm{AC}$ breakdown voltage is $15 \mathrm{kV}$ while the maximum AC breakdown voltage is $40 \mathrm{kV}$. Figure 2 (a) shows the dielectric strength of the MI oil versus the electrical breakdown shot number. In general, the dielectric strength of the MI oil decreases with an increase in the number of electrical breakdown shots. Figure 2 (b) shows the corresponding histogram of the MI oil, which was plotted based on $150 \mathrm{AC}$ breakdown voltage readings for the three MI oil samples. It can be seen from Figure 2 (b) that the data are skewed to the left, where most of the data fall on the left side of the histogram. This is known as a negatively skewed distribution. The mean and median are likely to the left of the mode. The tail is longer at the left-hand side. The results indicate that the breakdown of the MI oil frequently occurs at a lower voltage 
$(\leq 25 \mathrm{kV})$. Meantime, Figure 3 shows the regression line fitted to the AC breakdown voltage values for MI oil, which was plotted based on 150 AC breakdown voltage readings for the three MI oil samples. The regression equation obtained for the MI oil is also stated in Figure 3. Based on the regression line, it indicates a linear slope with electrical breakdown shot number coefficient is -0.1749 . This coefficient represents the mean decrease of AC breakdown voltage in kilovolts for every additional 1 shot of electrical breakdown.

Table 3. AC breakdown voltage in kilovolts $(\mathrm{kV})$ for the MI and NEI oil samples

\begin{tabular}{|c|c|c|c|c|c|c|c|c|c|c|c|c|c|c|}
\hline \multirow[b]{2}{*}{$\begin{array}{l}\overline{0} \\
\overline{0} \\
0 \\
0 \\
0 \\
\stackrel{0}{\circ}\end{array}$} & \multirow[b]{2}{*}{ 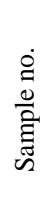 } & \multirow[b]{2}{*}{ 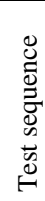 } & \multicolumn{10}{|c|}{ Electrical breakdown shot no. } & \multirow[b]{2}{*}{ 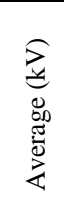 } & \multirow[b]{2}{*}{ 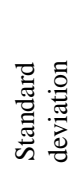 } \\
\hline & & & 1 & 2 & 3 & 4 & 5 & 6 & 7 & 8 & 9 & 10 & & \\
\hline \multirow{13}{*}{$\sum$} & \multirow{5}{*}{1} & 1 & 27 & 19 & 32 & 22 & 28 & 22 & 18 & 25 & 25 & 18 & \multirow{5}{*}{24} & \multirow{5}{*}{4.76} \\
\hline & & 2 & 27 & 29 & 35 & 24 & 17 & 21 & 21 & 19 & 19 & 15 & & \\
\hline & & 3 & 40 & 28 & 28 & 21 & 28 & 24 & 19 & 20 & 20 & 21 & & \\
\hline & & 4 & 29 & 29 & 29 & 28 & 27 & 25 & 21 & 22 & 22 & 19 & & \\
\hline & & 5 & 23 & 26 & 26 & 23 & 23 & 24 & 18 & 22 & 22 & 21 & & \\
\hline & \multirow{5}{*}{2} & 1 & 29 & 31 & 20 & 24 & 20 & 22 & 17 & 20 & 22 & 24 & \multirow{5}{*}{21} & \multirow{5}{*}{3.64} \\
\hline & & 2 & 26 & 16 & 19 & 23 & 19 & 19 & 18 & 20 & 20 & 20 & & \\
\hline & & 3 & 25 & 20 & 23 & 19 & 20 & 16 & 16 & 15 & 22 & 18 & & \\
\hline & & 4 & 25 & 17 & 28 & 20 & 21 & 16 & 16 & 21 & 23 & 18 & & \\
\hline & & 5 & 27 & 24 & 21 & 24 & 21 & 15 & 17 & 18 & 20 & 19 & & \\
\hline & \multirow{5}{*}{3} & 1 & 31 & 33 & 30 & 24 & 24 & 18 & 25 & 16 & 22 & 17 & \multirow{5}{*}{24} & \multirow{5}{*}{4.81} \\
\hline & & 2 & 21 & 22 & 24 & 30 & 26 & 24 & 17 & 21 & 26 & 16 & & \\
\hline & & 3 & 31 & 34 & 26 & 23 & 21 & 23 & 26 & 20 & 16 & 20 & & \\
\hline \multirow{17}{*}{ 武 } & & 4 & 30 & 31 & 21 & 23 & 21 & 27 & 19 & 21 & 20 & 25 & & \\
\hline & & 5 & 31 & 28 & 21 & 22 & 16 & 27 & 18 & 22 & 17 & 21 & & \\
\hline & \multirow{5}{*}{1} & 1 & 26 & 32 & 35 & 32 & 38 & 39 & 38 & 33 & 39 & 35 & \multirow{5}{*}{32} & \multirow{5}{*}{5.66} \\
\hline & & 2 & 35 & 27 & 29 & 30 & 35 & 34 & 31 & 33 & 34 & 26 & & \\
\hline & & 3 & 30 & 31 & 37 & 32 & 38 & 19 & 39 & 34 & 40 & 37 & & \\
\hline & & 4 & 35 & 27 & 18 & 29 & 26 & 27 & 27 & 33 & 28 & 42 & & \\
\hline & & 5 & 32 & 27 & 19 & 32 & 36 & 35 & 25 & 42 & 25 & 38 & & \\
\hline & \multirow{5}{*}{2} & 1 & 27 & 27 & 30 & 30 & 28 & 28 & 28 & 28 & 28 & 29 & \multirow{5}{*}{27} & \multirow{5}{*}{3.40} \\
\hline & & 2 & 23 & 22 & 23 & 18 & 25 & 31 & 22 & 29 & 29 & 27 & & \\
\hline & & 3 & 22 & 25 & 30 & 25 & 24 & 25 & 29 & 29 & 24 & 27 & & \\
\hline & & 4 & 29 & 29 & 28 & 25 & 29 & 28 & 30 & 16 & 26 & 30 & & \\
\hline & & 5 & 26 & 26 & 33 & 30 & 27 & 27 & 30 & 20 & 32 & 28 & & \\
\hline & \multirow{5}{*}{3} & 1 & 31 & 26 & 27 & 39 & 36 & 33 & 28 & 36 & 36 & 45 & \multirow{5}{*}{32} & \multirow{5}{*}{5.18} \\
\hline & & 2 & 28 & 31 & 34 & 28 & 33 & 34 & 35 & 30 & 36 & 40 & & \\
\hline & & 3 & 31 & 31 & 34 & 26 & 36 & 37 & 20 & 35 & 36 & 29 & & \\
\hline & & 4 & 28 & 36 & 35 & 30 & 25 & 37 & 31 & 34 & 43 & 35 & & \\
\hline & & 5 & 20 & 20 & 30 & 34 & 30 & 26 & 34 & 30 & 31 & 33 & & \\
\hline
\end{tabular}

By contrast, based on Table 3 the average AC breakdown voltage for the NEI oil is higher than that for the MI oil, with a range of 27-32 kV. The minimum and maximum AC breakdown voltage values for the NEI oil are 16 and $45 \mathrm{kV}$, respectively. Likewise, the dielectric strength and histogram were plotted for the NEI oil, and the results are shown in Figure 4 (a) and 4 (b), respectively. It can be observed that the dielectric strength increases gradually with respect to the number of electrical breakdown shots. It can be seen from Figure 4 (b) that the data are skewed to the right, where most of the AC breakdown voltage data fall on the right side of the histogram. This is also known as a positively skewed distribution. The mean and median are likely to the right of the mode. The tail is longer at the right-hand side. The results indicate that the breakdown of the NEI oil frequently occurs at a higher voltage $(\geq 25 \mathrm{kV})$. On the other hand, Figure 5 shows the regression line fitted to the average AC breakdown voltage values for NEI oil, which was plotted based on $150 \mathrm{AC}$ breakdown voltage readings for the three MI oil samples. The regression equation obtained for the MI oil is also stated in Figure 5. Based on the regression line, it indicates a linear slope with electrical breakdown shot number coefficient is +0.0996 . This coefficient represents the mean increase of AC breakdown voltage in kilovolts for every additional 1 shot of electrical breakdown. 




(a)



(b)

Figure 2. Distribution data of MI oil, (a) AC breakdown voltage data of the MI oil with respect to the electrical breakdown shot number, (b) histogram of the AC breakdown voltage

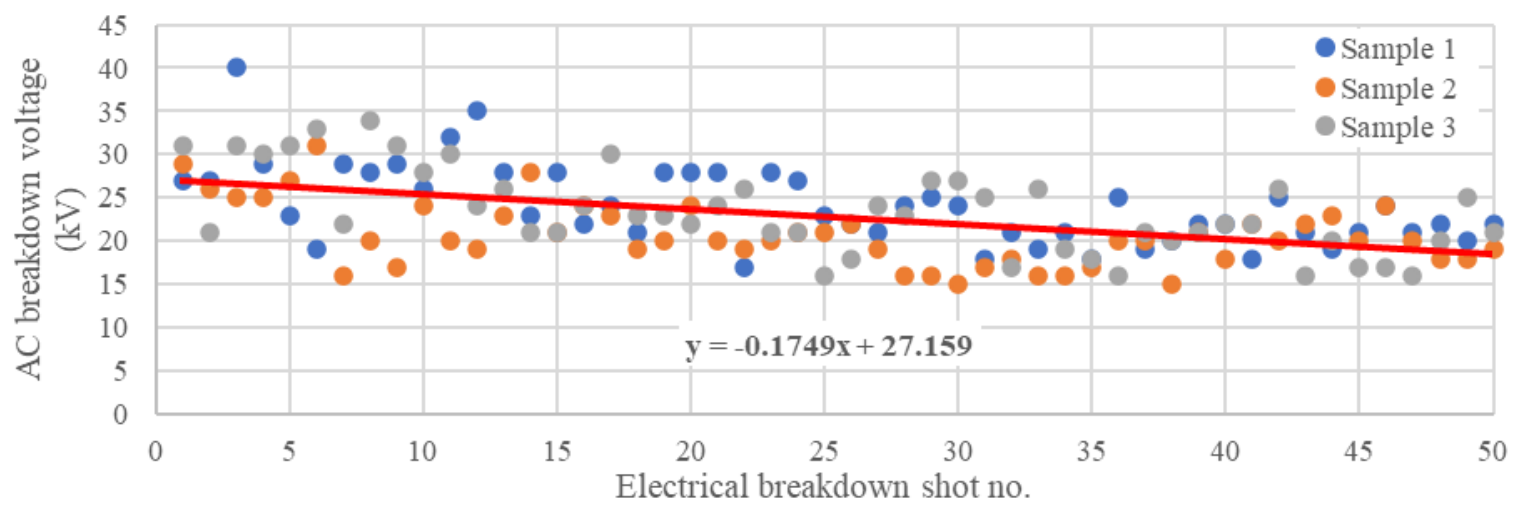

Figure 3. Regression line fitted to the AC breakdown voltage values for the overall MI oil samples

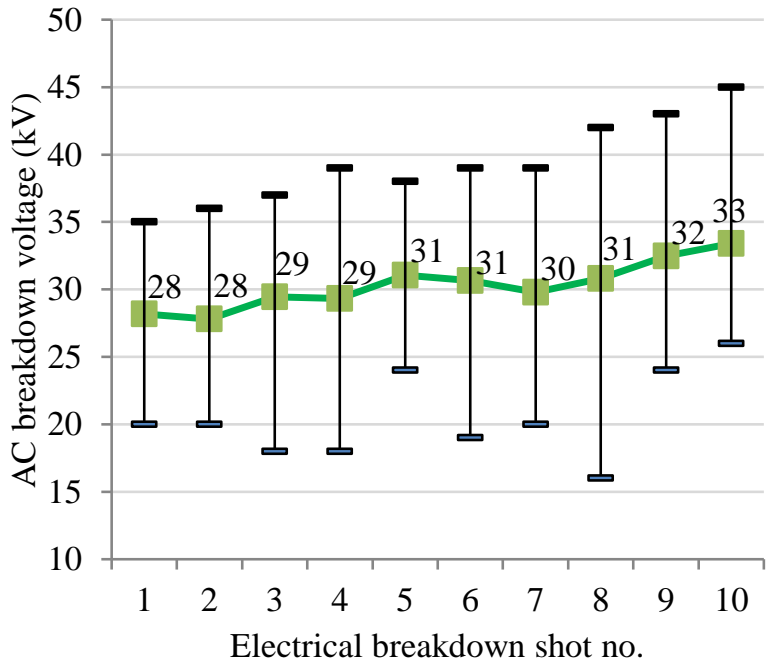

(a)

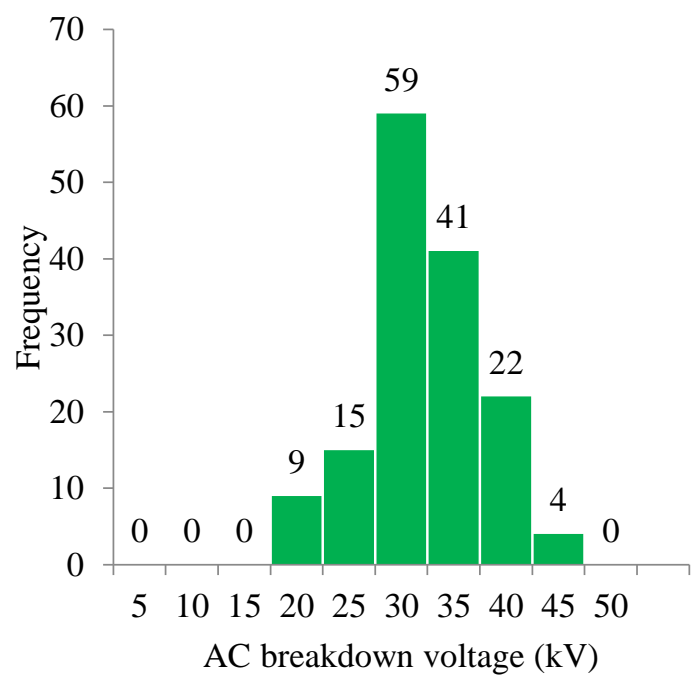

(b)

Figure 4. Distribution data of NEI oil: (a) AC breakdown voltage data of the MI oil with respect to the electrical breakdown shot number and (b) histogram of the AC breakdown voltage 


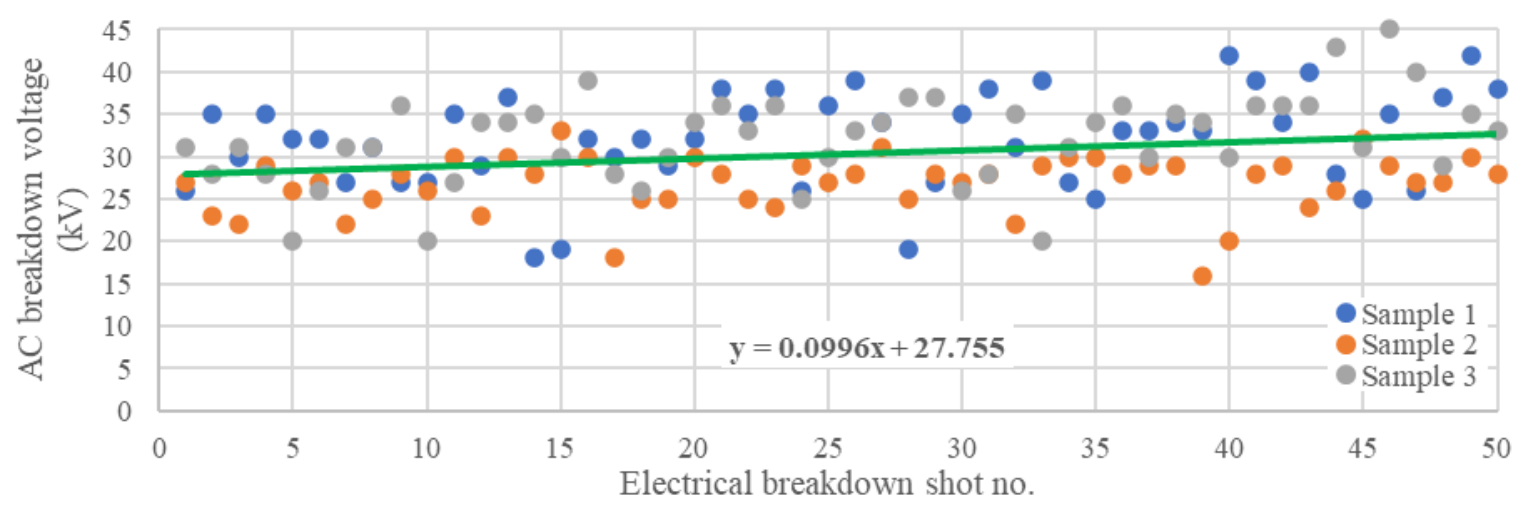

Figure 5. Regression line fitted to the AC breakdown voltage values for the overall NEI oil samples

Based on Figure 2 and Figure 4, it is apparent that the dielectric strength of the MI oil tends to decrease with an increase in the number of electrical breakdown shots. By contrast, the dielectric strength of the NEI oil tends to increase gradually as the number of electrical breakdown shots increases. Based on the histograms (Figure 2 (b) and Figure 4 (b)), the MI oil shows a left-skewed distribution, where most of the AC breakdown voltage data occur at a lower voltage $(\leq 25 \mathrm{kV})$. By contrast, the NEI oil shows a right-skewed distribution, where most of the breakdown voltage data occur at a higher voltage $(\geq 25 \mathrm{kV})$. It can be deduced that the NEI oil has higher dielectric strength than the MI oil, where $94 \%$ of 150 breakdowns occur at a voltage of more than $20 \mathrm{kV}$ for the NEI oil. By contrast, only $65.3 \%$ of 150 breakdowns occur at a voltage of more than $20 \mathrm{kV}$ for the MI oil. According to the ASTM D1816 standard, the AC breakdown voltage is considered as the minimum threshold for the insulating oil for a 1-mm electrode gap distance setup.

In general, the NEI oil has a higher percentage of minimum "pass" AC breakdown voltage compared with the MI oil. The NEI oil has better durability than the MI oil in terms of the dielectric strength, where most of the AC breakdown voltage data occur at a voltage of more than $20 \mathrm{kV}$. This is possibly due to the fact that NEI oil is hydrophilic (i.e., a substance that attracts water) and thus, the oil is capable of mixing well with water and dissolve water. In addition, the water saturation limit of the NEI oil is 5-8 times greater than that of the MI oil [4], [15]-[18]. The electrical stress may influence the molecular bonds (breakdown of $\mathrm{C}-\mathrm{H}$ bond) of the MI oil, which reduces its breakdown voltage [18]-[24]. The chemical composition of the NEI oil is different compared to that of the MI oil, which is a petroleum hydrocarbon. This leads to differences in the AC breakdown voltage behavior between the MI and NEI oils. Other factors may also influence the AC breakdown voltage of an insulating oil, such as the relative concentration of moisture (relative to its solubility) and water content [25].

\section{CONCLUSION}

In this study, the durability of MI and NEI oils in terms of the dielectric strength under repeated electrical breakdown was assessed. Based on the results, it can be concluded that the NEI oil has better dielectric strength where the average breakdown voltage for every 10 consecutive electrical breakdowns is higher compared with that for MI oil. Furthermore, the dielectric strength of the NEI oil shows a gradual increasing trend with respect to the number of electrical breakdown shots. The histograms also reveal that most of the AC breakdown voltage data are on the higher end $(\geq 25 \mathrm{kV})$ for the NEI oil compared with those for the MI oil. Hence, it is concluded that the NEI oil tested in this study is more durable compared with the MI oil.

\section{ACKNOWLEDGEMENTS}

The authors acknowledge the support provided by the Ministry of Higher Education Malaysia and Universiti Teknikal Malaysia Melaka in funding the study under the grant: (FRGS/1/2020/FKECERIA/F00416). The authors also thank Mr. Mohd Wahyudi Md Hussain from Faculty of Electrical Engineering, UTeM for providing assistance on the preparation and measurements of the materials used in this study. The authors also wish to thank Ms. Nadia Abdullah from The Golden Touch Language-Editing Service for proofreading this paper. 


\section{REFERENCES}

[1] I. Fofana, "50 years in the development of insulating liquids," in IEEE Electrical Insulation Magazine, vol. 29, no. 5, pp. 13-25, September-October 2013, doi: 10.1109/MEI.2013.6585853.

[2] D. M. Mehta, P. Kundu, A. Chowdhury, V. K. Lakhiani and A. S. Jhala, "A review on critical evaluation of natural ester vis-a-vis mineral oil insulating liquid for use in transformers: Part 1," in IEEE Transactions on Dielectrics and Electrical Insulation, vol. 23, no. 2, pp. 873-880, April 2016, doi: 10.1109/TDEI.2015.005370.

[3] D. M. Mehta, P. Kundu, A. Chowdhury, V. K. Lakhiani and A. S. Jhala, "A review of critical evaluation of natural ester vis-a-vis mineral oil insulating liquid for use in transformers: Part II," IEEE Transactions on Dielectrics and Electrical Insulation, vol. 23, no. 3. 2016. doi: 10.1109/TDEI.2016.005371.

[4] I. Fernández, A. Ortiz, F. Delgado, C. Renedo and S. Pérez, "Comparative Evaluation of Alternative Fluids for Power Transformers," Electric Power Systems Research, vol. 98, pp. 58-69, May 2013, doi: 10.1016/j.epsr.2013.01.007.

[5] M. Rafiq, M. Shafique, A. Azam, M. Ateeq, I. A. Khan and A. Hussain, "Insulation Systems for High Voltages Applications," Molecules, vol. 25, no. 3901, 2020, doi: 10.3390/molecules25173901.

[6] S. Ab Ghani, N. A. Muhamad, Z. A. Noorden, H. Zainuddin, N. Abu Bakar and M. A. Talib, "Methods for improving the workability of natural ester insulating oils in power transformer applications: A review," Electric Power Systems Research, 2017, doi: 10.1016/j.epsr.2017.10.008.

[7] ASTM D3487, "Standard Specification for Mineral Insulating Oil Used in Electrical Apparatus," 2009.

[8] ASTM D6871, "Standard Specification for Natural (Vegetable Oil) Ester Fluids Used in Electrical Apparatus," 2008.

[9] M. Baur, L. Calcara and M. Pompili, "Scatter reduction of the 50-60 Hz breakdown voltage test for insulating liquids," IEEE Transactions on Dielectrics and Electrical Insulation, vol. 22, no. 5, pp. 2401-2407, October 2015, doi: 10.1109/TDEI.2015.005471.

[10] W. F. Schmidt, "Elementary Processes in the Development of the Electrical Breakdown of Liquids," IEEE Transaction on Electrical Insulation, vol. EI-17, no. 6, pp. 478-483, 1982, doi: 10.1109/TEI.1982.298520.

[11] I. S. Chairul, S. A. Ghani, N. A. Bakar, M. S. A. Khiar, A. H. Zulkefli and A. A. Ahmad, "In-Service Transformer Oil Regeneration Based on Laboratory-Scale Process," Journal of Advanced Research in Fluid Mechanics and Thermal Sciences, vol. 79, no. 1, 2020, doi: 10.37934/ARFMTS.79.1.2735.

[12] J. S. N'cho, I. Fofana, Y. Hadjadj and A. Beroual, "Review of Physicochemical-Based Diagnostic Techniques for Assessing Insulation Condition in Aged Transformers," Energies, vol. 9, no. 5, pp. 367, 2016, https://doi.org/10.3390/en9050367.

[13] D. Martin and Z. D. Wang, "Statistical analysis of the AC breakdown voltages of ester based transformer oils," IEEE Transactions on Dielectrics and Electrical Insulation, vol. 15, no. 4, pp. 1044-1050, August 2008, doi: 10.1109/TDEI.2008.4591226.

[14] Y. Xu, S. Qian, Q. Liu and Z. Wang, "Oxidation stability assessment of a vegetable transformer oil under thermal aging," IEEE Transactions on Dielectrics and Electrical Insulation, vol. 21, no. 2, pp. 683-692, Apr. 2014, doi: 10.1109/TDEI.2013.004073.

[15] A. Reffas, A. Beroual and H. Moulai, "Comparison of breakdown voltage of vegetable olive with mineral oil, natural and synthetic ester liquids under DC voltage," IEEE Transactions on Dielectrics and Electrical Insulation, vol. 27, no. 5, pp. 1691-1697, Oct. 2020, doi: 10.1109/TDEI.2020.008308.

[16] R. Villarroel, B. García de Burgos and D. F. García, "Moisture dynamics in natural-ester filled transformers," International Journal of Electrical Power and Energy Systems, vol. 124, no. 106172, 2021, doi: 10.1016/j.ijepes.2020.106172.

[17] A. Rajab, M. Tsuchie, M. Kozako, M. Hikita and T. Suzuki, "Properties of thermally aged natural esters used as insulating liquid," International Journal on Electrical Engineering and Informatics, vol. 10, no. 2, pp. 220,-231, 2018, doi: 10.15676/ijeei.2018.10.2.2.

[18] L. Loiselle, I. Fofana, J. Sabau, S. Magdaleno-Adame and J. C. Olivares-galvan, "Comparative studies of the stability of various fluids under electrical discharge and thermal stresses," IEEE Transactions on Dielectrics and Electrical Insulation, vol. 22, no. 5, pp. 2491-2499, October 2015, doi: 10.1109/TDEI.2015.7311022.

[19] S. A. Ghani, N. A. Bakar, I. S. Chairul, M. S. A. Khiar and N. H. A. Aziz, "Effects of moisture content and temperature on the dielectric strength of transformer insulating oil," Journal of Advanced Research in Fluid Mechanics and Thermal Sciences, vol. 63, no. 1, pp. 107-116, 2019.

[20] S. A. Ghani, N. A. Muhamad, I. S. Chairul and N. Jamri, "A Study of Moisture Effects on the Breakdown Voltage and Spectral Characteristics of Mineral and Palm Oil-Based Insulation Oils," ARPN Journal of Engineering and Applied Sciences, vol. 11, no. 8, pp. 5012-5020, 2016.

[21] J. S. N'Cho, I. Fofana, A. Beroual, T. Aka-Ngnui and J. Sabau, "The gassing tendency of various insulating fluids under electrical discharge," IEEE Transactions on Dielectrics and Electrical Insulation, vol. 18, no. 5, pp. 16161625, October 2011, doi: 10.1109/TDEI.2011.6032832.

[22] I. Fofana, A. Bouaicha, M. Farzaneh, C. Volat and J. Sabau, "On the stability of mineral insulating oils under electrical stress,” 2009 IEEE Electrical Insulation Conference, May 2009, no. June, pp. 482-486. doi: 10.1109/EIC.2009.5166395.

[23] A. Reffas et al., "Influence of thermal ageing and electrical discharges on uninhibited olive oil properties," IET Science, Measurement and Technology, vol. 10, no. 7, pp. 711-718, 2016, doi: 10.1049/iet-smt.2016.0045.

[24] T. Toudja, H. Moulai, A. Nacer, A. Beldjilali, I. Khelfane and A. Debche, "Moisture and electrical discharges effect on naphthenic mineral oil properties," IET Science, Measurement \& Technology, vol. 8, no. 6, pp. 588-594, 2014, doi: 10.1049/iet-smt.2013.0262. 
[25] ASTM D1816-12, “Standard Test Method for Dielectric Breakdown Voltage of Insulating Liquids Using,” ASTM International, West Conshohocken, PA, pp. 1-5, 2012, doi: 10.1520/D1816-12.2.

\section{BIOGRAPHIES OF AUTHORS}
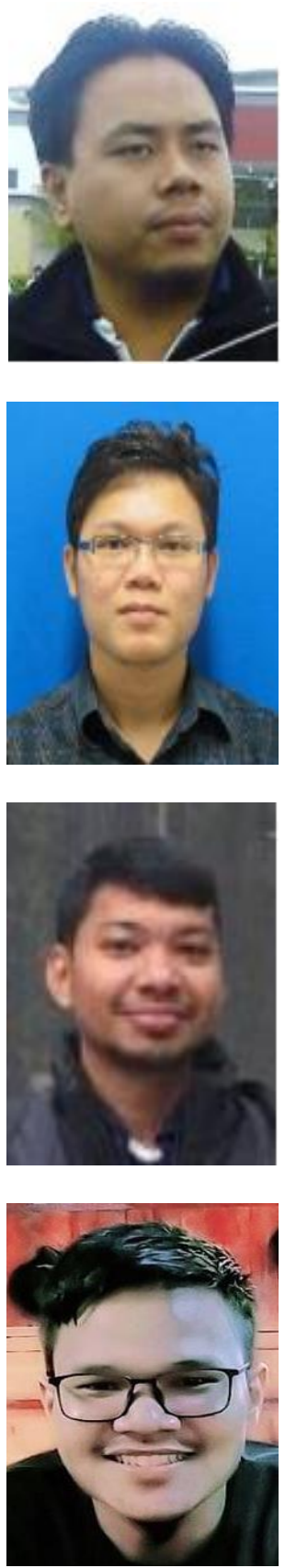

Sharin Ab Ghani received his BEng. (Hons.) degree in Electrical Engineering from Universiti Teknikal Malaysia Melaka (UTeM) in 2008, MEng. Degree in Electrical Engineering from Universiti Tenaga Nasional in 2012, and PhD degree in Electrical Engineering from Universiti Teknologi Malaysia in 2019. Currently, he is serving as Senior Lecturer at Faculty of Electrical Engineering, UTeM and Head of Energy and Power Systems (EPS) Research Group. His research interests are centered on high voltage engineering, condition monitoring of power equipment, eco-friendly electrical insulation, design of experiments, and optimization. He also has experience in consultation work with industries related to electrical installation design, transformer condition assessment, and partial discharge analysis.

Mohd Shahril Ahmad Khiar was born in Selangor, Malaysia in 1984. He received his BSc. In Electrical \& Electronics Engineering from Korea University in 2008, Master's degree in Electrical Engineering from Universiti Tenaga Nasional in 2012, and PhD degree from University of Southampton, UK in 2019. He is currently serving as Senior Lecturer at Faculty of Electrical Engineering, UTeM and Head of High Voltage Engineering Research Laboratory in UTeM, where he is also the Deputy Head of Energy and Power Systems (EPS) Research Group. His research interests include high voltage engineering and insulation materials, sensors, condition monitoring for power equipment, and asset management. Since 2013, he has published over 20 refereed conference and journal papers associated with the transformer condition monitoring and asset management.

Imran Sutan Chairul was born in Kuala Lumpur, Malaysia, in 1984. He received his BEng. (Hons.) degree in Electrical Engineering from Universiti Teknikal Malaysia Melaka (UTeM) in 2008 and MEng. degree in Electrical Engineering from Universiti Tenaga Nasional in 2012. $\mathrm{He}$ is currently pursuing his $\mathrm{PhD}$ degree at UTeM, where his research is focused on vegetablebased transformer dielectric liquids.

Muhammad Imran Zamir was born in Pulau Pinang, Malaysia in 1997. He received his BEng (Hons.) degree in Electrical Engineering from Universiti Teknikal Malaysia Melaka in 2018 